\title{
PART 3
}

Cultural Networks, Public Knowledge 
Edhem Eldem - 9789004375741

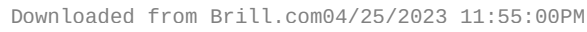
via free access 


\title{
Introduction
}

\author{
Edhem Eldem
}

Was Jerusalem an Ottoman city at the turn of the twentieth century? The answer may seem obvious. On paper, most of the actors of Ottoman Jerusalem's cultural and intellectual networks were indeed Ottoman subjects, soon to become citizens. This is certainly true of Khalil Sakakini, Sacid al-Husayni, Ruhi al-Khalidi, Wasif Jawharriyeh as a child (as Issam Nassar's contribution makes clear), and perhaps even of Pinhas Grayevsky. It was less true, however, of Eliezer Ben-Yehuda (as Hassan Ahmad Hassan and AbdulHameed al-Kayyali discuss), the Franciscan friars of the Custody of the Holy Land, and thousands of Jewish settlers intent on making a fresh start in the Promised Land. Yet labels and nationalities are tricky, and one recalls the bon mot attributed to Yorgo Boşo Efendi, deputy of Serfidje (today's Servia, in Greece): "I am as Ottoman as the Ottoman Bank." We are still trying to figure out what he may have really meant.

There is no doubt that Ottomanness in Jerusalem before World War I was contextual, and likely to change according to circumstances. As Yair Wallach points out in his chapter in this volume, Sakakini is a case in point when he brandishes his carte de visite in a gesture of allegiance to the springtime of Ottoman peoples in the wake of the Young Turk Revolution. Yet should we not instead see Sakakini as an exception, and a short-lived one at that, to a growing estrangement of Jerusalem from a gradually dissolving Ottoman commonwealth? How Ottoman could the city's cultural networks really have been if Arabs and Jews were discussing their ownership rights over Palestine (see the contributions by Wallach and Jonathan Gribetz), if Jewish newspapers were forging the future of the Hebrew language (Gribetz), and if Christian authorities were setting up printing houses that served primarily sectarian goals, as in the cases of the Tipografia di Terra Santa and the St. James Armenian Printing House (cases studied by Leyla Dakhli and Arman Khatchatryan, respectively)? The chapters in this part examine these case studies and, in so doing, address the question of Ottomanness.

The Ottoman archives give a rather telling image of the ambiguous presence of the state in the cultural life of the city. Apart from a number of events typical of the Hamidian period, such as the opening of an imposing primary school

1 Tarlk Zafer Tunaya, Türkiye'de Siyasal Partiler [Political parties in Turkey], vol. 3 (Istanbul: Hürriyet Vakfı Yayınları, 1987), 173.

(C) EDHEM ELDEM, 2018 | DOI:10.1163/9789004375741_018

This is an open access chapter distributed under the terms of the prevailing CC-BY-NC-ND License at the time of publication. 
in $1890,{ }^{2}$ the state generally seemed to be "in the backseat," trying to catch up with local initiatives by granting (or not) its support and permission. Not surprisingly, requests concerning printing presses and publishing houses were particularly frequent, in ways that resonate with some of the contributions in this part. Thus, in October 1907, the "Latin monasteries of Jerusalem and Jaffa, under French protection" obtained full exemption from customs dues on two August Fomm printing presses weighing two tons, worth 27,000 piasters $\left(£_{250}\right){ }^{3}$ In 1903, the central bureaucracy had to deal with requests from Menahem Shmoyil and Aaron Weiss, two Austrian subjects, and Moshe Azrail, an Ottoman subject, to open printing houses in Jerusalem. Shmoyil and Weiss' project involved publications in "diverse languages" (elsine-i muhtelife); Azrail's was deemed particularly important because it would become the first Sephardic printing house in a market dominated by a multitude of Ashkenazi ventures. ${ }^{5} \mathrm{~A}$ few years later, just months before the revolution, an Ottoman subject and Jerusalemite by the name of Nikola Petro obtained permission to set up a press dedicated to the printing of kart dö vizit (business cards). ${ }^{6}$

The voices of Ottomans from the center may give a better idea of the growing distance that appears to have developed between Istanbul and Jerusalem. In his memoirs, Mehmed Tevfik Bey [Biren] (1867-1956), governor of Jerusalem from 1897 to 1901, recalls the awkward position in which he found himself in an unfamiliar cultural and social environment. Particularly striking was his ambiguous stance with respect to the consuls of the Great Powers, whose local power and prestige by far exceeded his own, but whose company he enjoyed much more than he did the locals'. At a public lecture organized by the Latin community, Tevfik Bey was offered a chair next to a throne-like seat reserved for the French consul. He was spared the embarrassment of having to leave by the consul himself, Ernest Auzépy, "a very civil and delicate man," who chose not to come, "probably realizing how inappropriate the situation would have been." To Tevfik Bey, the French and British consuls had become "proper friends," a qualification he never used for any of the local inhabitants of Jerusalem:

2 Ottoman State Archives (вОА), MF. мкт. 120/94, 29 Muharrem 1308/September 14, 1890; FTG 1876 , ca. 1890 .

3 BOA, ŞD. 601/75, October 9/22, 1323/1907.

4 вОА, DH. мКт. 688/34, February 8/21, 1318/1903-August 24/September 6, 1319/1903.

5 вОА, DН. МКт. 682/6, March 15/28, 1319/1903-September 4/17, 1319/1903.

6 воА, DH. Мкт. 1240/15, February 27/March 11, 1323/1908.

7 Fatma Rezan Hürmen, ed., Bir Devlet Adamının Mehmet Tevfik Bey'in (Biren) II. Abdülhamid, Meşrutiyet ve Mütareke Devri Hatıraları [The memoirs of a statesman: Mehmet Tevfik Bey (Biren) during the constitutional and armistice periods], vol. 1 (Istanbul: Arma Yayınları, 1993), 95 .

8 Ibid., 96. 
There were several famous families in the district of Jerusalem, known by the names of Husayni, Khalidi, Nashashibi, Alami, Dawudi. The Husaynis and the Khalidis, who had accumulated the greatest power and had become rivals, could never get along. Those who had the preference of the local government would increase their power and eliminate the others. $^{9}$

Relations with the locals were tense. In July 1898 , a local Jew warned the governor to drink only milk that was milked in plain sight, for fear that "the Arabs would put a spell on it, to loosen him up as they had İbrahim Pasha." Tevfik Bey started drinking cocoa in the morning, instead of milk: "A spell on milk would have done me no harm, but I was worried they would mix it with something or dip their filthy hands in it." 10

The protracted rivalries between bell and clock towers in the city were arguably the strongest indications of Ottoman fragility in Jerusalem. In 1901, at a time generally associated with the erection of clock towers to celebrate Abdülhamid II's silver jubilee, it was Kaiser Wilhelm II who had a 47-meter tower built to accompany the Church of the Dormition, for which he had, during his visit in 1898 , forcefully obtained a plot of land right next to the Muslim-controlled tomb of David." ${ }^{11}$ The clock tower became a bone of contention between the Ottoman and German governments because its use as a bell tower infuriated the local Muslim population. The German chancellery tried to justify the situation by arguing that such practice "should have no harm in a city - like Jerusalem - where the population is used to hearing the sound of bells," but it was finally forced to accept that the bells be silenced by removing the clappers, levels, and ropes. ${ }^{12}$

A victory for the Ottomans? Perhaps, if we are to believe that the monks of Mount Zion really kept to their promise. More significantly, the belated realization of the state's own clock tower was a source of Ottoman frustration. The decision was taken only in May 1907, based on a rather clear argument: "While the city of Jerusalem is filled with clock towers showing alla franca time, that there should not be a single clock tower to display the sunset-based (ezānī)

\footnotetext{
$9 \quad$ Ibid., 102.

10 Ibid., 104-5.

11 BOA, i. HUS. 87/74, March 11/24, 1317/1901; веO 1637/122736, March 13/26, 1317/1901; HR. sYs. 410/2, 6 Zilhicce 1318/March 27, 1901; DH. мкт. 2470/28, March 27/April 9, 1317/1901. For an account of the events that led to the granting of the deed, see Hürmen, Bir Devlet Adamı, 123-34.

BOA, HR. SYs. 410/2, May 16, 1909-March 4/17, 1326/1910.
} 
time is unacceptable from the viewpoint of both religion and wisdom." It was therefore decided to spend some 1,500 liras, collected from the population, to build "a very strong and beautiful tower in the elegant Arab architectural style."13 The project was signed and supervised by a non-Muslim Jerusalemite, Pascal Mina. This last-minute effort by the empire to mark the city with its imprint, while at the same time paying lip service to some form of regionalism, was short-lived. It had the misfortune of being on the path of Allenby's victorious march into the city and of attracting British criticism as "an ultra-hideous clock tower." It was dismantled and moved to Allenby Square outside the city walls, only to be demolished in $1934 ;^{14}$ a tragic end that echoes the fragility of the Ottoman presence and domination in the last decades of the empire.

13 вОА, Dн. мКт. 1174/42, April 24/May 7, 1323/1907; Ү. РRк. Uм. 80/69, October 15/28, 1323/1907.

14 Uzi Baram, "Out of Time: Erasing Modernity in an Antique City," Archaeologies:Journal of the World Archaeological Congress 8 no. 3 (2012): 339-42. 